\title{
Politica of Criminal Law; The Importance of Revision of Mineral and Coal Law: Who Is Benefitted
}

\author{
Arif Rohman ${ }^{1}$, Syafruddin ${ }^{1} \&$ Mansyur Masnyur ${ }^{1}$ \\ ${ }^{1}$ Department of Criminal Law, Faculty of Law, Universitas Borneo Tarakan, Indonesia \\ Correspondence: Arif Rohman, Department of Criminal Law, Faculty of Law, Universitas Borneo Tarakan Jl. \\ Pantai Amal Lama No. 1 Tarakan-North Kalimantan, Indonesia. Tel: 62-813-2860-2427. E-mail: \\ arifrohman_ubt@yahoo.com
}

Received: August 15, 2020

Accepted: September 26, $2020 \quad$ Online Published: October 13, 2020

doi:10.5539/jpl.v13n4p156

URL: https://doi.org/10.5539/jpl.v13n4p156

\begin{abstract}
Minerals and coal are state owned assets that need to used wisely, although the People's Representative Council (DPR) is yet to ratify them for the 2020-2025 period during the COVID-19 pandemic that has ravaged the world, including Indonesia. The review of the Mineral and Coal has caused many draw backs because it does not follow the principle of balancing and sharing regional authority. This study discusses the principle of strict liability as stipulated in Law No. 3/2020 by examining the urgency for changes and who will benefit from the revision. Doctrinal research was used for analyzing the politics of criminal Law in the Mineral and Coal, both before and in its amendments. Furthermore, Law No. 4/2009 ensnares many people that carry out illegal mining because the mechanism and procedure for the popular Mining license is the same with the mining license of the companies. The content of the amendments to the Mineral and Coal only regulates the sale of $51 \%$ foreign shares, but from a criminal perspective and nominalization of criminal fines and the reduction of prison sentence, it can be seen that the new criminal concept does not have a significant meaning for business corporations, as the suspects so far have been people that have been mining in the form of community mining.
\end{abstract}

Keywords: criminal law politics, urgency, revision, minerals and coal

\section{Introduction}

Minerals and coal are natural mining resources that cannot be renewed. However, amid the controversy and the COVID-19 epidemic that has ravaged various countries, this has not dampened the enthusiasm of lawmakers to discuss and ratify the Minerals and Coal Act. (Anisatul Ummah, 2019). The drafted Law on Minerals and Coal has been proposed to be reviewed as a five-year national legislation program since 2010 (Ikhwan, 2015). Although changes in the national legislation program often occurs due to the needs of the political elite, which was then resubmitted in February 2015.

There are several reasons for the House of Representatives (DPR) to accelerate the discussion of the Minerals and Coal Act, both in terms of political and general interests. Politically, the acceleration of discussion and ratification based on certainty for mining companies, at least for the first generation companies that already have a license in the form of a Mining Agreement or an abbreviated PKP2B, which will expire in 2020 (Adhi Wicaksono, 2019). There are at least eight companies whose contracts will expire, including PT. Tanito Harum, which ended January 14, 2019, PT. Arutmin Indonesia ended on November 1, 2020, PT. Kendilo Coal Indonesia ended on September 13, 2021, PT. Kaltim Prima Coal will end on December 31 2021, PT. Multi Harapan Utama ended on April 1, 2022, PT. Adaro Indonesia ends on October 1, 2022, PT. Kideko Jaya Agung, the contract period ends on March 12, 2023, and PT. Berau Coal has a license until April 262016.

The form of profit from mining activities is an investment, creation of jobs and the proudest of these is the state's source of income in the form of Non-Tax State Revenue (PNBP). It was noted that in 2018 the amount of PNBP from the mining sector was about Fifty trillion rupiah or around $156 \%$ of the target (Anastasia Arvirianty, no date).

Although the mining sector contributes significantly to the government source of revenue, the Mineral and Coal Mining sector also leaves various problems both sectoral and non-sectoral. The problems that have surfaced are indications of a criminal act of corruption and environmental pollution problems, both during exploration and transportation. The history of mining in Indonesia shows that no company has ever been convicted of the Minerals 
and Coal Act. So far, the violations involve people that do not have a mining license. In 2011, the Indonesian National Police recorded 190 criminal cases in the mining sector (Nugroho, 2012). Illegal mining cases have increased; between 2013-2017, there were about 1,384 illegal mining cases (Fathulrahman, 2019). At the normative level, the government had a dilemma, such as mining businesses carried out by communities, which do not have license and non-standard mining equipment, this situation is a criminal act. On the other hand, the community had to deal with providing the basic needs of life, and the role of the government should be to guide and facilitate mining activities carried out by the community to become legitimate (Redi, 2016).

In-constrast to large-scale mining, they can quickly meet mining standard. The problem, however, is that many companies are breaking the Minerals and Coal Act when it comes to ensuring and implementing post-mining reclamation. It was recorded that only thirty per cent of the 1,444 Mining Business license holders have provided post-mining guarantees, and 1,735 mining holes in Indonesia are left unchecked without any reclamation or rehabilitation efforts from mining companies (Thomas, 2019). Furthermore, about 3,121 companies holding mining business license do not provide post-mining guarantees in 2019, and 1895 domestic investment companies have also not placed reclamation guarantees. The existence of mineral and coal mining businesses, both on a small and large scale, has had a negative impact. Exploration and transportation efforts have an impact on the environment, and problems persist even after mining business are closed. These problems includes air pollution, loss of biodiversity and even result in death due to abandoned puddles.

\section{Methods}

The method used in this research is categorized as doctrine (Muhdar, 2019), also known as juridical-normative (Soekanto, 2019). In addition, the model contains a normative character with the goal of a set of ethical criminal sanctions norms contained in Law No. 4/2009 and No. 3/2020. The approach focuses on solving the political problem of criminal Law that built in the handling of criminal acts in the mining sector, especially minerals and coal.

This study prioritizes legal materials in the form of Laws, such as Law No. 4/2009 and its amendment therefore, the case and mining data are also needed. This is related to the reasons for reforming the Mineral and Coal Mining regulations in Indonesia. The principal and additional penalties contained in the regulation are analyzed conceptually, based on the principle of ultimate premium and the principle of strict liability of the perpetrators of mining crimes.

\section{Result and Discussion}

\subsection{Special Criminal Law}

Before discussing the mineral and coal Law policy, the concept of a particular criminal Law will first be explained. In addition, the concept of division of criminal Law has various types, there is a difference between general criminal Law and special criminal Law. Suppose the concept of general criminal Law is prevailing Law that is intended and applies to people as legal subjects without distinguishing the quality of certain individual legal subjects. Criminal law provisions that are largely outside the penal code or formally are therefore not covered by criminal procedural law (Hiariej, 2014).

The concept of specific criminal Law can also be interpreted in such a way that a legal product that contains criminal requirements can be be qualified as a special criminal Law (Supriyadi, 2016). Furthermore, the special Criminal Law aims at a particular thing in the criminal field, which usually lies in its provisions that are regulated outside the Criminal Code relating to general criminal Law. There are deviations from the general criminal Law, which is referred to in the institution that is empowered to judge.

Although the distinction between general criminal Law and special criminal Law can be interpreted easily, it should be clear that the content of the distinction is influenced by criminal liability. According to Moore, qouted by Cane, general and specific comparisons are a theoretical (and, incidentally, descriptively accurate) method criminal Law, since it has an objective whose achievement requires the fulfilment of two separate criteria, such as error and responsibility for the perpetrator. criminal act (Cane, 2007).

In Indonesia, it is easier to draft regulations than to reform some form of codification of criminal Law (KUHP), because there are interests from various parties and therefore it is not easy to be practiced like in European countries. Regarding the distribution and characteristics of the criminal Law, the Minerals and Coal Law is a unique crime, although it does not include the types of acts related to content that is contain in the criminal law.

\subsection{Mining Law}

Mining Law is the general rule of Law that controls the state authority in the management of minerals (mining) 
and controls legal ties between the country and individuals and/or legal entities in the management and utilization of minerals (mining) (Salim HS, 2014a). The translation of mining Law from English, such as in Dutch, which means mijnrecht, while in German, the equivalent word is bergrecht. In addition, Joan Kuyek stated the definition of mining Law as a legislation designed to safeguard the interests of the mining sector and mitigate disputes between mining firms by making it transparent by stating the the group that have the right to mine. Furthermore, it was never intended to regulate mining or its effects on land or citizens, therefore other legislation need to be look into in order to safeguard such interests (Salim HS, 2014b).

Modern mining legislation aims to secure the benefits of resource uses while promoting the social and environmental responsible discovery, growth and distribution of mineral resources while reducing environmental degradation and growing rivalry for land usage. Mining assets are fixed expenses, irreversibly related to a single mining field, which takes several years of recovery. Protection of tenure is the most important aspect of realistic mining regulations (Long, 1995).

Legislation regulates the ownership, sales and activities of mining, quarries and wells, and the access to natural resources around the world. The exploitation of natural resources from the planet regulated by different Laws relating to mining and minerals. The Federal and State governments have mining and mineral regulations to safeguard the health and welfare of workers, promote the productive usage of natural resources, preserve the atmosphere and increase tax revenues.

Mining are excavations in the soil and sub-soil that are extracted from ores, iron or other natural resources. The mineral is a precious, inert matter produced by the powers of nature and exists either on or on the earth. The possessive belief in minerals in the soil is a mineral privilege. Mineral rights holders are free to access and confiscate property in order to extract minerals, therefore anyone can possess mineral rights and mine resources without being the owner of the property ('Mine and Mineral Law', 2008a).

Coal mining, the physical exploitation of energy resources for energy production; also the discovery, production, refining and transportation of coal in one way or another. In addition, coal has always been an important form of electricity, but air emissions and climate change, which lead to more than many widely used fossil fuels, have contributed to a decrease in the usage of coal in many developing countries and a drop in coal mining ('Coal Mining', 2003).

Teguh Prasetyo argues that the characteristics or specificities and deviations of special criminal Law against material criminal Law interpreted as follows: 1. Criminal Law with an elastic character 2. Attempt and help to carry out a criminal act are punishable with a penalty 3 . Specific provisions relating to criminal acts and violations 4. Expansion of the enforcement of territorial principles 5. Legal subjects related to/determined on the basis of financial losses and the economy of the country 6 . State employees are a particular legal subject 7. Have an open character, which means that it is mandatory to commit an offense covered by another law as long as it guarantees that it will become a criminal act 8 . The penalty added one third to corporation 9 The confiscation of movable and immovable objects 10 . There are criminal acts that are not only regulated in Law 11. Criminal acts have a transnational character 12. There is a jurisdiction requirement from another country for criminal acts that is committed. 13. Criminal acts can have a political nature (Renggong, 2016).

\subsection{Political Criminal Law, Mineral and Coal Law}

In a simple term, mining regulations can be understood as a set of state regulations and ethics that live in the community, and control mining activities as a whole based on social justice for natural energy sources (Haryadi, 2018). The history of the formulation of mineral and coal mining policy in Indonesia began in 1967, marked by the enactment of Law No. 11/1967. Furthermore, this regulation lasted 42 years, and after the reformulation was carried out, it was replaced by Law No. 4/2009, one of the essential issues of change is the control of the State in the mineral and coal mining sector by taking into account the concept of division of government affairs.

The exploitation of natural resources from the areas regulated by different Laws relating to mining and minerals, therefore government have set up regulations to safeguard the health and welfare of workers, promote the productive usage of natural resources, preserve the atmosphere and increase tax revenues ('Mine and Mineral Law', 2008b).

There are many coal mining in East Kalimantan, and this area is also known as the mining area. However, it is sad because the remaining mine that has being recycled generate a new problem, such as coal mine pits of about 1,735. The impact of not carrying out reclamation was the death of several residents that fell into the mine puddle. Although local governments have issued policies to strengthen the Law, which are not sufficient (Toumbourou et al., 2020). 


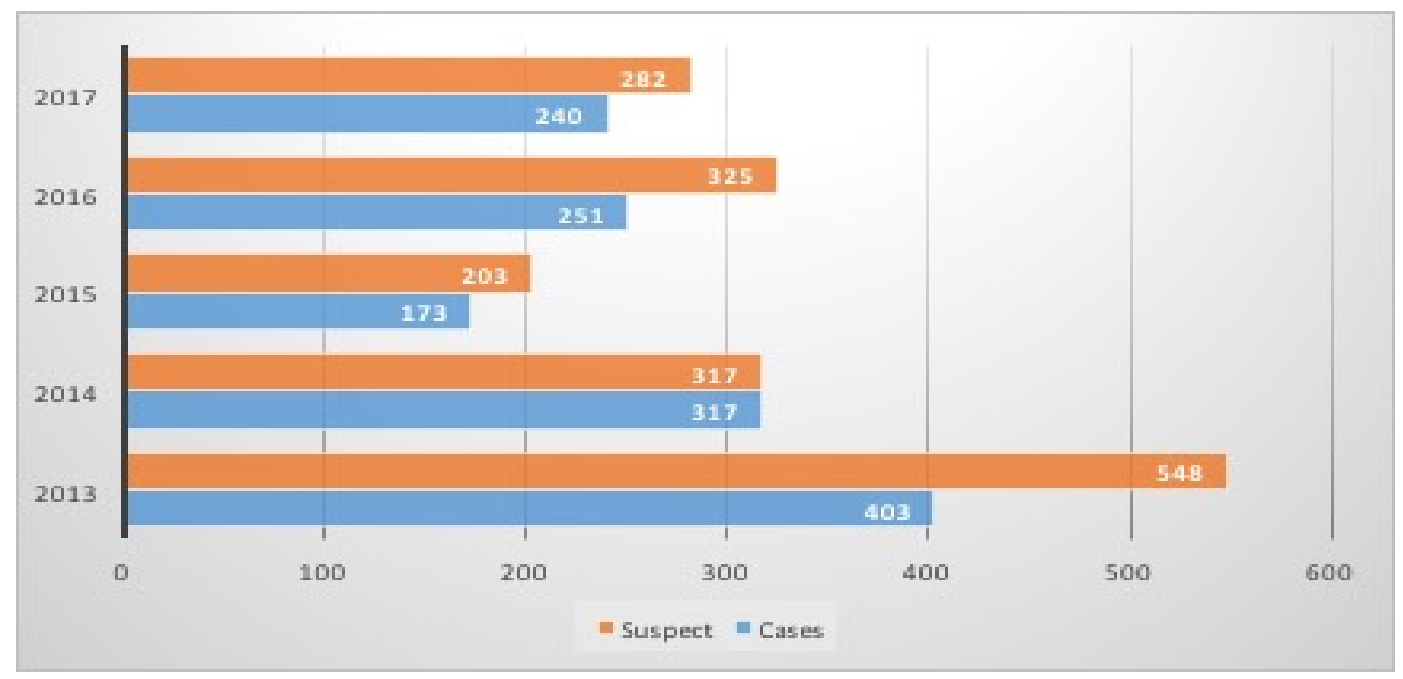

Figure 1. Illegal mining

The number of criminal cases in the mining sector, both mineral and coal, in several regions and on average is the public and not the company. This situation is caused by conditions related to four things, such as the aspect of policy, modality, institutions and technology or the environment (Zulkarnain, 2013). Furthermore, the happenings are policy outlined in Law No. 4/2009 relating to People's Mining, which state that people are positioned like a company in such a way that the society with limited resources in terms of capital and technology will not be able to fulfil what is required by the Law. Besides, the community is also required to carry out mining in a in environment, with this provision, the community must carry out mining in an area that has been determined by the government even though there is certainty about the potential for the existence of mining goods in such area.

Criminal acts in the mineral and coal mining sector, when referring to the concept of types of acts, are categorized as particular crimes, such as the existence of criminal provisions in statutory regulation. The perpetrators' responsibility was implemented through strict criminalization (Gallagher, 2002). When discussing the problem of criminalization, four critical points were noted, first is the protection of individuals related to losses. The second is the protection of individuals II talking about the rights of others. The third is the protection of moral values, and the fourth is the protection of Collective Interest (Hörnle, 2015).

Law enforcement agencies should be more persuasive in responding to the phenomenon of illegal mining, not only acting and prosecuting, but also evaluating the forms and patterns of mining carried out by the community, especially the lack of concern between the central and regional governments in empowering those that lead to illegal mining. 
Table 1. The main criminal provisions in LAW No. 4 of 2009

\begin{tabular}{|c|c|c|}
\hline Legal Basis & Types of Crime & $\begin{array}{l}\text { Types of Sanctions } \\
\text { (maximal form) }\end{array}$ \\
\hline Art 158 & Mining business without a license & $\begin{array}{l}\text { Ten years in prison and a fine of } 10 \\
\text { billion rupiah }\end{array}$ \\
\hline Art 159 & $\begin{array}{l}\text { The submission of reports on mining results is } \\
\text { incorrect }\end{array}$ & $\begin{array}{l}\text { Ten years in prison and a fine of } 10 \\
\text { billion }\end{array}$ \\
\hline $\begin{array}{c}\text { Article } 160 \\
\text { paragraph (1) }\end{array}$ & Exploration without IUP and IUPK & $\begin{array}{l}\text { One year prison and a fine of } 200 \\
\text { million rupiah }\end{array}$ \\
\hline $\begin{array}{c}\text { Article } 160 \\
\text { paragraph (2) }\end{array}$ & Production IUP but conducting production operations & $\begin{array}{l}\text { Five years in prison and a fine or } \\
10 \text { billion rupiah }\end{array}$ \\
\hline Article 161 & $\begin{array}{l}\text { Collecting, utilizing, processing, refining, exploiting, } \\
\text { selling non-license holders }\end{array}$ & $\begin{array}{l}\text { Ten years in prison and a fine of } 10 \\
\text { billion rupiah }\end{array}$ \\
\hline Art 162 & Obstruct or interfere with mining business activities & $\begin{array}{l}\text { One year imprisonment and a fine } \\
\text { of } 100 \text { million }\end{array}$ \\
\hline Article 163 & Corporate actors & Weighted $1 / 3$ of the maximum fine \\
\hline Art 165 & Abuse of authority to grant permission & $\begin{array}{l}\text { Two years in prison and a fine of } \\
200 \text { million rupiah }\end{array}$ \\
\hline
\end{tabular}

Various concepts are related to the means used to handle environmental crimes (minerals and coal) through nonpenal means or using the ultimate premium principle in such a way that the policy that must build is a restorative justice approach in environmental restoration (Pujiyono, 2016). In fact, Law No. 4/2009 has accommodated the ultimum remidium principle, however, the reality is that many mining companies are ignoring because they are not complying. There are no strict sanctions from the State due to the need for supply and State revenue from mining products. It was reported that in 2014 the total reclamation and post-mining guarantee funds that were not paid by several companies amounted to IDR 165 trillion (Supervisi, 2014).

One of the policies issued by the transferor in dealing with the complexities of mineral and coal mining was to review the regulations according to the political concept of criminal Law as expressed by Soedarto that there are two essential elements. The first is an attempt to create reasonable regulations according to circumstances and situations. The two policies issued by this competent institution are desired and expected to be used to achieve the desired goals (Maroni, 2016).

Table 2. Necessary criminal provisions in law No. 3 of 2020

\begin{tabular}{ccl}
\hline No. & Legal Basis & \multicolumn{1}{c}{ Sanction Type (maximum form) } \\
\hline 1 & Art 158 & Five years in prison and a fine of 100 billion rupiah \\
2 & Art 158 & Five years in prison and a fine of 100 billion rupiah \\
3 & Art 160 & Five years in prison and a fine of 100 billion rupiah \\
4 & Article 161 & Five years in prison and a fine of 100 billion rupiah \\
5 & Article 161A & Two years in prison and a fine of 5 billion rupiah \\
6 & Article 161B & Five years in prison and a fine of 100 billion rupiah \\
7 & Art 162 & One year imprisonment and a fine of 100 million scholars \\
\hline
\end{tabular}

In addition to the underlying crimes, the reconstruction of the amendments to the mineral and coal Law provides an additional penalties in three forms. The first is a confiscation of goods used in the occurrence of a criminal act. The second is the deprivation of profits obtained from the proceeds of mining crime, and the third is the obligation to pay costs arising from the occurrence of a criminal act. For the third point, it is not included when the defendant 
is found guilty in court, in such a way that the defendant also bears the case fees incurred as a result of the mining crime. According to the author, the inclusion of this additional punishment is wrong.

Using the concept of strict liability is generally considered to be the most appropriate way to regulate high risk activities, such as environmentally hazardous production or genetic engineering. The reason for applying this principle is not only the efficient maintenance that needs to be carried out but also the degree of effectiveness of the activity risk itself. There is no direct relationship between perpetrator and victim, and this can only be achieved through strict responsibility but not through negligence rules (Nell and Richter, 2003).

Legal obligations related to the restoration of the environment to promote optimal reduction and progress in reducing the use of technology apply when the amount of compensation differs from the amount of environmental damage.. The imposition of strict responsibility as negligence and considering it as a strict responsibility always causes distortion, whereas negligence only does the same if the compensation is much smaller than the level of environmental damage, and it is nice when Law No. 3/2020 does not have any means of adjustment under strict responsibility (Endres and Friehe, 2011).

The concept of responsibility must strictly differentiate its meaning from negligence, and this is to reduce the level of activity of the perpetrator rather than the level of activity of the victim (Nemeth, 2012). The concept developed in Law No. 3/2020 is the choice of strict liability and negligence depending on the extent to which there is an exchange of risks of reciprocity between perpetrators and victims, and the extent of benefits, in addition to externalized risks. This responsibility interpreted as legal liability based on error and the use of fines/ mixed detention (Cory and Germani, 2002). As for the reformulation of the types of violations, it explained as follows:

Table 3. Legal basis for criminal acts in Law No. 3/2020

\begin{tabular}{cll}
\hline No. & \multicolumn{1}{c}{ Deed } & \multicolumn{1}{c}{ Legal Basis } \\
\hline 1 & Do not have a business license & Art 35 \\
\hline 2 & $\begin{array}{l}\text { Transferring the permits that obtained, either IPR, SIPB, IUP or } \\
\text { IUPK }\end{array}$ & $\begin{array}{l}\text { Article 70A, Article 86G letter a, } \\
\text { Article 93 paragraph (1) }\end{array}$ \\
\hline 2 & False reports on the implementation of People's Mining Business & Article 70 letter e \\
& activities & \\
\hline 3 & Palus reports on the sales results of extracted minerals and coal & Article 105 paragraph (4) \\
\hline 4 & $\begin{array}{l}\text { Periodic written reports (results of exploration and production } \\
\text { operations) }\end{array}$ & Article 110 \\
\hline 5 & $\begin{array}{l}\text { Periodic reports on work plans and implementation of mineral and } \\
\text { coal mining business activities }\end{array}$ & Article 111 paragraph (1) \\
\hline 6 & Hinders the settlement of land rights & Article 136 paragraph (2) \\
\hline 7 & Production operations without a license & Article 160 paragraph (2) \\
\hline
\end{tabular}

The criminal provision in Law No. 4/2009 and No. 3/2020 does not regulate compensation for the injured community, in such a way that even though it is a criminal act, it does not touch public justice at all, because of the imposition of fines. For the State, is there any certainty that the proceeds of the fines paid by the offender will be used immediately for the repair of the damage that has been caused by the violator of the Law? This is a big problem when the Law only applies to the fine sanctions without an explicit provision on the use of the excellent funds.

When observed more closely, it was observed that in the context of the mean rea is good as contained in Law No. $4 / 2009$, and its amendments are not so significant, the only nominalization of fines and reducing imprisonment alone. Although substantially, the objective of amending the Mineral and Coal Law, one is to divest $51 \%$ of shares and cut regional authority in granting mining license. In addition to the reformulation of share divestment, Law No. 3/2020 applies legitimacy to mining business actors that do not carry out the placement of reclamation and guarantees with a double-track system of penalties, such as imprisonment and a fine of 100 million rupiahs.

\section{Conclusions}

In essence, the primary criminal sanction changes in regulating minerals and coal acts are not as significant, since 
the offenders of criminal offences in the mineral and coal mining sector are people that carry out community mining. However, this change becomes legal for the government to be able to ensnare corporate actors that do no not provide reclamation and post-mining guarantee funds or do not carry out reclamation. The politics of criminal Law that build in addition to the renominalization of both imprisonment and fines are substantially very beneficial to the government because of the use of the principle of ultimum remidium and the principle of strict liability to corporate actors. However, when viewed from the licensing procedure, it is not beneficial to the community.

\section{References}

Adhi, W. (2019). Dewan Perwakilan Rakyat Targetkan Revisi Undang-Undang Minerba Kelar Agustus, CNN Indonesia.

Anastasia, A. (n.d.). Miris, 74 Tahun Merdeka Masih Marak Tambang Ilegal Di RI. Retrieved June 2, 2020, from https://www.cnbcindonesia.com/news/20190819164116-4-93066/miris-74-tahun-merdeka-masih-maraktambang-ilegal-di-ri

Anisatul, U. (2019). Ketua Komisi VII DPR Targetkan RUU MInerba Kelar Agustus 2020, CNBC. Retrieved May 26, 2020, from https://www.cnbcindonesia.com/news/20191211185848-4-122342/ketua-komisi-vii-dprtargetkan-ruu-minerba-kelar-agustus-2020

Cane, P. (2007). The general/special distinction in criminal law, tort law and legal theory. Law and Philosophy, 26(5), 465-500.

Coal Mining. (2003). McGraw-Hill Dictionary of Scientific \& Technical Terms. Retrieved from https:/encyclopedia2.thefreedictionary.com/coal+mining.

Cory, D. C., \& Germani, A. R. (2002). Criminal sanctions for agricultural violations of the Clean Water Act. Water Policy, 4(6), 491-514.

Endres, A., \& Friehe, T. (2011). R\&D and abatement under environmental liability law: Comparing incentives under strict liability and negligence if compensation differs from harm. Energy Economics. Elsevier B.V., $33(3), 419-425$.

Fathulrahman, A. (2019). Ada 1.384 Tambang Ilegal pada 2013-2017 Ditindak Bareskrim, CNN Indonesia.

Gallagher, J. J. (2002). The Application of Strict Criminal Liabilities to Spillage of Oil: The Practical Impact on Effective Spill Response. Spill Science \& Technology Bulletin, 7(1), 39-44. https://doi.org/10.1016/S13532561(02)00059-2.

Haryadi, D. (2018). Pengantar Hukum Pertambangan Mineral dan Batubara. Balunijuk: UUB Press.

Hiariej, E. O. (2014). Prinsip-Prinsip Hukum Pidana (1st ed.). Yogyakarta: Cahaya Atma Pustaka.

Hörnle, T. (2015). Theories of Criminalization. The Oxford Handbook of Criminal Law, (July 2018), pp. 1-27.

Ikhwan. (2015). Revisi Undang-Undang Minerba Kebutuhan Mendesak.

Long, K. R. (1995). Economics of mining law. Nonrenewable Resources, 4(1), 74-83.

Maroni. (2016). Pengantar Politik Hukum Pidana. Lampung: CV Anugrah Utama Raharja.

Mine and Mineral Law. (2008a). West's Encyclopedia of American Law (2nd ed.). Retrieved from https://legaldictionary.thefreedictionary.com/Mine+and+Mineral+Law

Mine and Mineral Law. (2008b) West's Encyclopedia of American Law2 (2nd ed.). Retrieved from https://legaldictionary.thefreedictionary.com/Mine+and+Mineral+Law.

Muhdar, M. (2019) Penelitian Doctrinal Dan Non-Doctrinal Pendekatan Aplikatif dalam Penelitian Hukum. Pertama. Samarinda: Mulawarman University Press.

Nell, M., \& Richter, A. (2003). The design of liability rules for highly risky activities - Is strict liability superior when risk allocation matters? International Review of Law and Economics, 23(1), 31-47.

Nemeth, C. P. (2012). 5 - Criminal Liability of Security Personnel (4th ed.). Boston: Butterworth-Heinemann.

Nugroho, A. C. (2012). Kasus Pertambangan: POLRI Proses 190 Kasus Pidana.

Pujiyono, P. (2016). Corporation Criminal Responsibility Model Based on Restorative Justice Approach in Indonesia. Diponegoro Law Review, 1(1), 127.

Redi, A. (2016). Dilema Penegakan Hukum Penambangan Mineral Dan Batubara Tanpa Izin Pada Pertambangan Skala Kecil (Dilemma of Law Enforcement in Small Scale Illegal Mining). Rechtsvinding, 5(3), 399-420. 
Renggong, R. (2016) Hukum Pidana Khusus: Memahami Delik-Delik di Luar KUHP (1st ed.). Jakarta: Kencana Prenada Media Group.

Salim, H. S. (2014a). Hukum Pertambangan di Indonesia (7th ed.). Jakarta: PT Raja Grafindo Persada.

Salim, H. S. (2014b). Hukum Pertambangan Mineral \& Batubara. Kedua. Edited by Tarmizi. Jakarta: Sinar Grafika.

Soekanto, S. dan S. M. (2019). Penelitian Hukum Normatif Suatu Tinjauan Singkat (19th ed.). Depok: PT Rajagrafindo Persada.

Supervisi, K. D. A. N. (2014). Koordinasi dan supervisi pengelolaan pertambangan mineral dan batubara 19 provinsi di indonesia. Retrieved from https://acch.kpk.go.id/images/ragam/gn-sda/gn-sda-pertambangan/03KORSUP-PERTAMBANGAN-DAN-MINERBA_BALI.pdf

Supriyadi, S. (2016). Penetapan Tindak Pidana Sebagai Kejahatan Dan Pelanggaran Dalam Undang-Undang Pidana Khusus. Mimbar Hukum - Fakultas Hukum Universitas Gadjah Mada, 27(3), 389.

Thomas, V. F. (2019) Jatam Sebut 70 Persen Lubang Tambang Belum Direklamasi.

Toumbourou, T. et al. (2020). Political ecologies of the post-mining landscape: Activism, resistance, and legal struggles over Kalimantan's coal mines. Energy Research and Social Science.

Zulkarnain, I. (2013). Pertambangan Ilegal di Indonesia dan Permasalahannya. Jakarta. Retrieved from http://iesr.or.id/files/Pertambangan Ilegal di Indonesia.pdf

\section{Copyrights}

Copyright for this article is retained by the author(s), with first publication rights granted to the journal.

This is an open-access article distributed under the terms and conditions of the Creative Commons Attribution license (http://creativecommons.org/licenses/by/4.0/). 